\title{
Perancangan Sistem Value Chain terhadap Prospek Pengumpulan E-Waste di Bank Sampah
}

\author{
Stephanus Kelvin ${ }^{1 *}$, Helena J. Kristina ${ }^{2}$, Eric Jobiliong ${ }^{3}$ \\ $1 *, 2,3)$ Jurusan Teknik Industri, Fakultas Sains dan Teknologi, \\ Universitas Pelita Harapan \\ Jl. Boulevard Palem Raya, Lippo Village, Tangerang, Banten 15811 \\ email : stephanuskelvin@gmail.com, helena.kristina@uph.edu, eric.jobiliong@uph.edu
}

\begin{abstract}
Electronic waste (e-waste) has become environmental issue in Indonesia. Several tons of e-waste was generated each year. Available landfills will not be sufficient to accommodate e-waste that people produce. Waste bank become one of many solutions to overcome this problem. Implementation of pilot project in waste bank is needed to see the prospects of e-waste collection in waste bank. Thus, the goal of this research is to design a value chain system for e-waste collection prospect in waste bank and system simulation as the foundation for implementing a pilot project. Simulations on 2 scenarios had been done to determine profitability of e-waste collections pilot project in waste bank. Based on simulation, it is known that there is profit generated from e-waste recycling process for 2 scenarios. Ranges of profit for 2 months are Rp. 7.963.879 - Rp. 40.447.047 for scenario 1 and Rp. 7.952.394 40.435.561 for scenario 2. If only PCB component that could be recycled, profit for 2 months still can be generated in the range Rp. $689.964 R p$. 6.398.486 for scenario 1 and Rp. $678.478 \mathrm{Rp}$. 6.387.000 for scenario 2. Thus, implementation of e-waste collections pilot project in waste bank is profitable.
\end{abstract}

Keywords: Waste Bank, E-Waste, Value Chain Management, Causal Loop Diagram, Waste Bank

\begin{abstract}
Abstrak
Sampah telah menjadi masalah fundamental lingkungan hidup di Indonesia. Sejumlah ton $e$-waste dihasilkan setiap tahunnya. Tempat Pembuangan Akhir (TPA) yang tersedia tidak akan cukup untuk mengakomodasi $e$-waste yang dihasilkan masyarakat. Bank sampah dapat menjadi salah satu dari banyak solusi untuk mengatasi masalah ini. Implementasi pilot project di bank sampah dibutuhkan untuk melihat prospek pengumpulan e-waste di bank sampah. Maka dari itu, tujuan penelitian ini ialah untuk merancang sistem value chain terhadap prospek pengumpulan e-waste di bank sampah dan membuat simulasi sistem tersebut sebagai fondasi dalam melakukan pilot project. Simulasi pada 2 skenario dilakukan untuk menentukan keuntungan pelaksanaan pilot project di bank sampah. Berdasarkan simulasi, diketahui bahwa terdapat keuntungan yang dihasilkan dari proses daur ulang e-waste untuk 2 skenario. Range keuntungan untuk 2 bulan berkisar antara Rp. 7.963.879 - Rp. 40.447.047 untuk skenario 1 and Rp. 7.952 .39440 .435 .561 untuk skenario 2. Jika hanya komponen PCB yang dapat didaur ulang, keuntungan untuk 2 bulan masih dapat dihasilkan dalam kisaran Rp. 689.964 Rp. 6.398 .486 untuk skenario 1 and Rp. 678.478 Rp. 6.387.000 untuk skenario 2. Maka, implementasi pilot project pengumpulan e-waste di bank sampah menguntungkan secara finansial.
\end{abstract}

Kata Kunci: Bank Sampah, Sampah Elektronik, Value Chain Management, Causal Loop Diagram, Pool Bank Sampah

${ }^{*}$ Korespondensi Penulis 


\section{Pendahuluan}

Sampah telah menjadi masalah fundamental lingkungan hidup di Indonesia. Timbunan sampah terus menumpuk dari waktu ke waktu. Pada tahun 2012, Kementerian Lingkungan Hidup mencatat rata-rata penduduk Indonesia menghasilkan sekitar 2,5 liter sampah per hari atau 625 juta liter dari jumlah total penduduk (Hendrawan, 2012). Berdasarkan Direktur Perumahan dan Permukiman Bappenas, Nugroho Tri Utomo, volume sampah di Indonesia seki$\operatorname{tar} 1$ juta meter kubik per hari, namun baru $42 \%$ diantaranya yang terangkut dan diolah dengan baik (Antara, 2015). Sampah yang tidak dapat diangkut setiap harinya diperkirakan sekitar 348.000 meter kubik atau sekitar 300.000 ton.

Tingginya nilai statistik sampah ini sangat erat kaitannya dengan perkembangan industri elektronik di Indonesia yang berkembang sungguh pesat. Berdasarkan data Badan Pusat Statistik (BPS) tahun 2012, jumlah produksi elektronik dalam negeri untuk dua jenis barang, yaitu televisi dan komputer sungguh signifikan. Indonesia mampu memproduksi televisi sebanyak $12.500 .000 \mathrm{~kg}$ per tahun dan mengimpor televisi sebanyak $6.687 .082 \mathrm{~kg}$ per tahun. Sementara untuk komputer, Indonesia mampu memproduksi $12.491 .899 .469 \mathrm{~kg}$ per tahun, dengan jumlah impor $35.344 .733 \mathrm{~kg}$ per tahun. Implikasi dari perkembangan industri elektronik ialah aliran perputaran barang elektronik menjadi sungguh cepat dimana produk elektronik generasi terbaru segera menggantikan produk generasi terdahulunya sehingga lama-kelamaan semakin menumpuk dan menjadi sampah elektronik $(e-$ waste).

E-waste dapat diartikan sebagai barangbarang elektronik dan peralatan elektrik yang sudah tidak dipakai, tidak dapat bekerja atau sudah tidak diinginkan karena sudah menjadi barang yang usang dan perlu dibuang, baik dalam bentuk keseluruhan atau sebagian (Agustina, 2011). Alat elektronik yang tidak terpakai cepat atau lambat akan berakhir di tempat pemrosesan akhir seperti landfill atau insinerator, dimana mereka akan mengeluarkan material beracun ke udara, tanah, dan air $(\mathrm{Wu}$, et al. 2008).

Penanganan masalah e-waste melalui TPA dinilai kurang tepat dan tidak dapat mengakomodir jumlah e-waste yang begitu melimpah sehingga muncul gagasan penanganan masalah sampah dengan penerapan sistem bank sampah. Penerapan prinsip 3R (Reduce, Reuse, Recycle) di bank sampah sebagai suatu sistem pengelolaan sampah kering secara kolektif mendorong masyarakat untuk berperan serta aktif di dalamnya. Maka dari itu, bank sampah dinilai sebagai tempat pemberdayaan masyarakat yang mungkin merupakan tempat yang paling cocok untuk menampung, memilah, dan mendistribusikan sampah seperti $e$-waste ke fasilitas penampungan/pengolahan sampah.

Berdasarkan penelitian Halim (2011), didapatkan hasil bahwa peluang untuk melaksanakan proyek percontohan pengumpulan limbah eletronik masih terbuka karena kemauan penduduk DKI Jakarta untuk mendaur ulang barang bekas masih cukup tinggi. Sebuah sistem value chain terhadap prospek pengumpulan $e$-wastedi bank sampah dinilai perlu sebagai fondasi dalam melaksanakan proyek percontohan pengumpulan limbah elektronik di bank sampah. Value chain management merupakan teknik yang luas digunakan dalam bidang manajemen operasi dan manajemen rantai pasok, untuk analisis dan perbaikan berkelanjutan terhadap utilisasi sumberdaya (Womack dan Jones, 1996).

Selain perancangan sistem value chain, simulasi terhadap biaya yang muncul pada proses pengangkutan sampah elektronik dan keuntungan yang diperoleh dalam proses daur ulang e-waste juga diperlukan untuk mengetahui prospek pelaksanaan proyek percontohan pengumpulan limbah elektronik di bank sampah. Dalam melakukan simulasi, terdapat beberapa skenario yang dibedakan berdasarkan ada tidaknya keterlibatan bank sampah induk. Keberadaan bank sampah induk didasarkan pada hasil rapat koordinasi nasional bank sampah ke-3 di Makassar yang menyatakan bahwa sebaiknya setiap kota/kabupaten di seluruh Indonesia membentuk bank sampah induk dengan tetap memberi ruang bagi terbentuknya bank sampah mandiri.

Berdasarkan permasalahan yang ada maka tujuan dari penelitian ini adalah merancang sistem value chain terhadap prospek pengumpulan e-waste di bank sampah dan membuat simulasi sistem value chain sebagai fondasi dalam melaksanakan proyek percontohan pengumpulan limbah elektronik di bank sampah. Studi kasus berada di bank sampah Tangerang Selatan.

\section{Metode Penelitian}

Bagian ini membahas langkah-langkah penyelesaian permasalahan penelitian ini. Proses pengerjaan penelitian ini dimulai dari pengumpulan data baik data umum maupun data khusus, dilanjutkan dengan pengolahan 
data, pelaksanaan simulasi, serta pembuatan kesimpulan dan saran. Langkah-langkah sistematis penelitian secara rinci ditampilkan pada Gambar 1.

\subsection{Pengumpulan dan Pengolahan Data}

Pengumpulan dan pengolahan data berisi hasil kuisioner perilaku pengelola bank sampah dengan prospek pengumpulan e-waste, pemetaan bank sampah Tangerang Selatan, sistem value chain, dan causal loop diagram.

\subsection{Kuisioner Perilaku Pengelola Bank Sampah dalam Kegiatan Daur Ulang dengan Prospek Pengumpulan E-waste di Bank Sampah}

Kusioner prospek pengumpulan e-waste dibuat untuk melihat peluang bank sampah sebagai tempat untuk menampung, memilah, dan mendistribusikan sampah elektronik usang kepada pihak pengelola. Adapun sebanyak 36 responden yang mengisi kuisioner ini, terdiri dari para pengurus bank sampah di Tangerang Selatan dan forum komunikasi (forkas) bank sampah Tangerang Selatan, serta para pemerhati lingkungan. Beberapa hasil kuisioner ditampilkan dalam penelitian ini.

Pada Gambar 2 mengenai tempat yang dikunjungi untuk mendaur ulang produk elektronik, $78 \%$ responden menyatakan bahwa bank sampah menjadi tempat untuk mendaur ulang produk elektronik. Sedangkan, 7\% responden memilih pom bensin dan masing-masing $6 \%$ responden memilih gedung perkantoran dan supermarket.

Dalam hal metode yang diharapkan untuk memudahkan masyarakat berpartisipasi dalam mendaur ulang limbah elektronik pada gambar $3,44 \%$ responden menyatakan bahwa metode yang paling tepat ialah menyetornya di bank sampah sebagai salah satu jenis sampah yang bisa ditabung. Sedangkan, $24 \%$ responden menyatakan program trade-in (tukar tambah) menjadi metode yang diharapkan, $20 \%$ responden menyatakan metode yang diharapkan ialah menaruh di drop off point (tempat tertentu), dan $10 \%$ responden menyatakan metode yang diharapkan ialah menaruh limbah tersebut di depan rumah. Hanya 2\% reponden meyatakan limbah elektronik harus dikirim melalui pos yang telah disediakan.

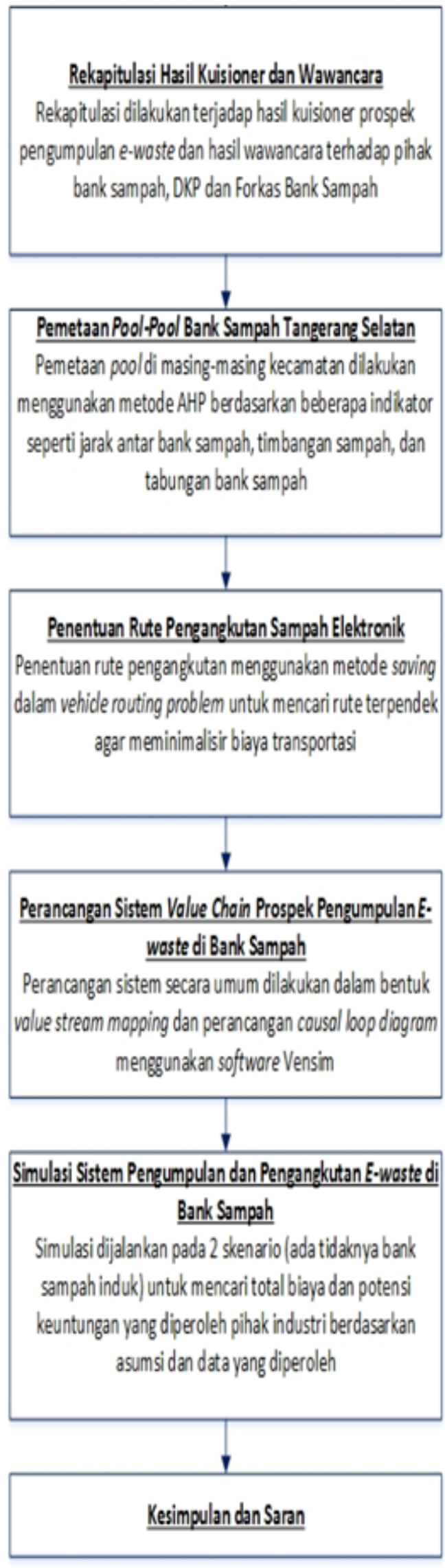

Gambar 1: Flow Chart Metode Penelitian 


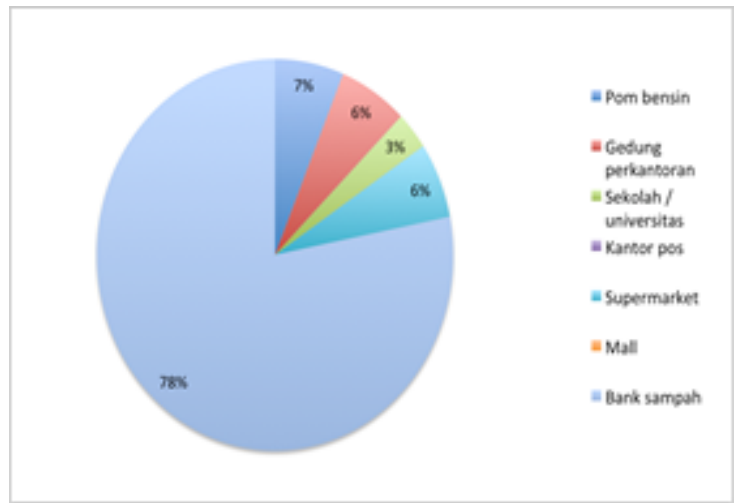

Gambar 2: Rekapitulasi Data Tempat yang Dikunjungi untuk Mendaur Ulang Produk Elektronik

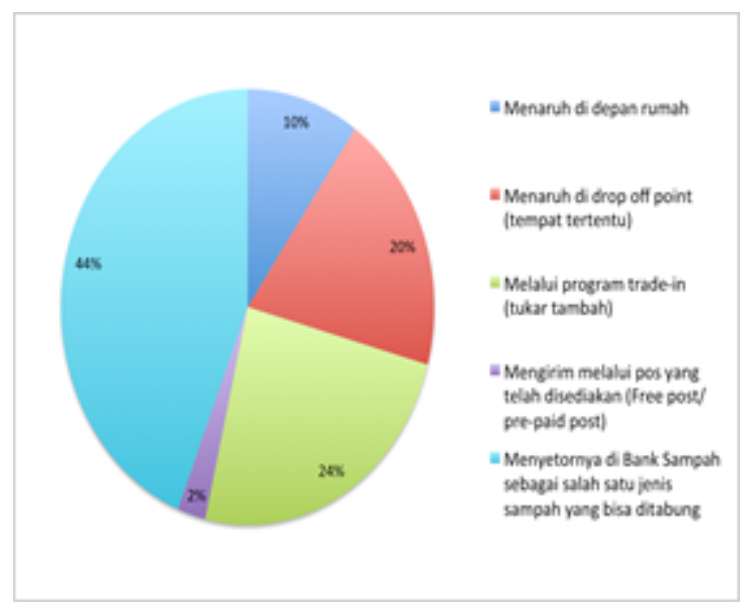

Gambar 3: Rekapitulasi Data Tempat yang Dikunjungi untuk Mendaur Ulang Produk Elektronik

\subsection{Pemetaan Bank Tangerang Selatan}

Pemetaan bank sampah dilakukan untuk memilih pool-pool bank sampah. Pool bank sampah merupakan bank sampah yang dipilih sebagai tempat penyimpanan sampah eletronik yang dikumpulkan dari bank sampah yang ada di sekitarnya dan tempat pengangkutan sampah elektronik oleh pihak industri pengolah sampah elektronik atau pihak bank sampah induk. Pool ini nantinya akan menjadi salah satu bagian dari mekanisme value chain management pengumpulan dan pengangkutan sampah elektronik. Gambar 4 menunjukan peta bank sampah.

Setelah memetakan bank-bank sampah di Tangerang Selatan, dilakukan pemilihan poolpool bank sampah di masing-masing daerah atau kecamatan. Pemilihan pool ini didasarkan pada

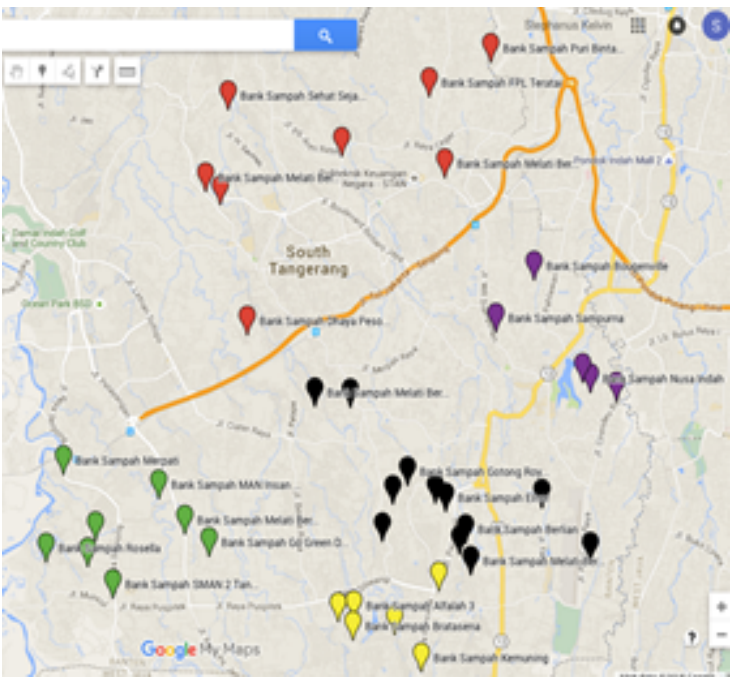

Gambar 4: Peta Bank Sampah Tangerang Selatan

Keterangan :

- Merah: kecamatan Pondok Aren

- Hijau: kecamatan Setu dan Serpong

- Ungu: kecamatan Ciputat Timur

- Hitam: kecamatan Pamulang 1

- Kuning: kecamatan Pamulang 2

Tabel 1: Asumsi Bobot Kriteria

\begin{tabular}{|c|c|c|}
\hline No. & Kriteria & Bobot \\
\hline 1. & Jarak $(\mathrm{km})$ & $50 \%$ \\
\hline 2. & Tabungan $(\mathrm{Rp})$. & $20 \%$ \\
\hline 3. & Timbangan $(\mathrm{kg})$ & $30 \%$ \\
\hline
\end{tabular}

beberapa indikator seperti jarak antar bank sampah, jumlah tabungan, dan kuantitas timbangan sampah menggunakan metode analytical hierarchy process. Maka dari itu, dilakukan pemberian bobot terhadap masing-masing faktor. Tabel 1 menunjukan asumsi bobot pada masing-masing kriteria.

Jarak menjadi kriteria yang paling penting dibandingkan tabungan dan timbangan sampah dengan bobot $50 \%$ karena faktor jarak akan bepengaruh langsung terhadap total biaya transportasi yang harus ditanggung oleh industri pengolah sampah elektronik. Kriteria timbangan memiliki tingkat kepentingan kedua tertinggi setelah jarak dengan bobot $30 \%$. Kriteria tabungan memiliki tingkat kepentingan terakhir dengan bobot $20 \%$. Setelah diketahui masing-masing bobot indikator, maka dilakukan pembobotan terhadap bank sampah di masing-masing kecamatan pada masing-masing indikator. Selanjutnya ditentukan pool bank 
Tabel 2: Pool Bank Sampah

\begin{tabular}{|c|l|}
\hline Kecamatan & Pool Bank Sampah \\
\hline Pondok Aren & $\begin{array}{l}\text { Bank Sampah } \\
\text { Asyainiyah }\end{array}$ \\
\hline Setu dan Serpong & $\begin{array}{l}\text { Bank Sampah Melati } \\
\text { Bersih Armapura }\end{array}$ \\
\hline Ciputat Timur & Bank Sampah Sampurna \\
\hline Pamulang 1 & $\begin{array}{l}\text { Bank Sampah Asri } \\
\text { Mandiri }\end{array}$ \\
\hline Pamulang 2 & $\begin{array}{l}\text { Bank Sampah Paud Ca- } \\
\text { haya Agung }\end{array}$ \\
\hline
\end{tabular}

sampah pada masing-masing kecamatan. Pool bank sampah yang telah terpilih dapat dilihat pada Tabel 2.

Bank sampah yang terpilih sebagai pool akan diberikan lambang yang berbeda dibandingkan dengan bank sampah lainnya pada GOOGLE MAP. Gambar 5 menunjukan peta bank sampah akhir dimana pool bank sampah sudah ditentukan dan dilambangkan dengan tanda bujur sangkar.

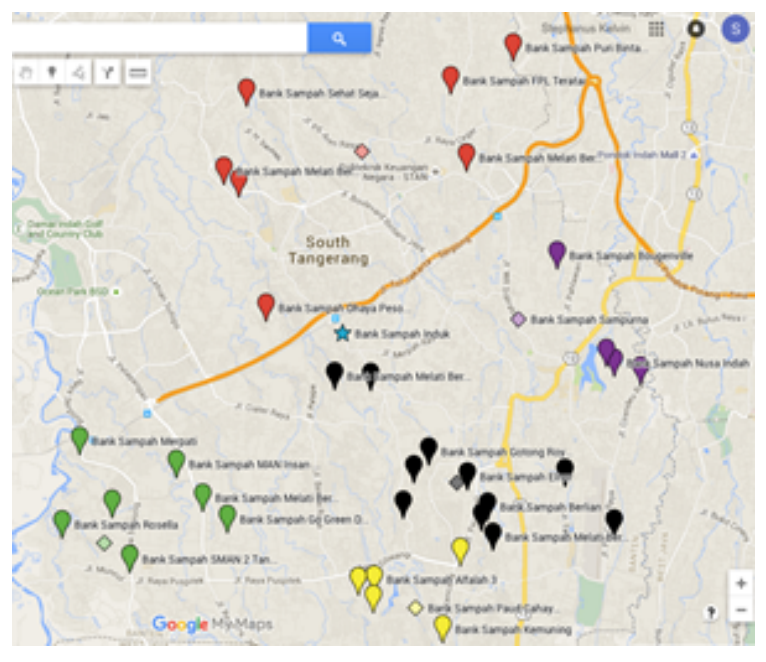

Gambar 5: Peta Bank Sampah Akhir

\subsection{Sistem Value Chain Prospek Pengumpulan E-waste di Bank Sampah}

Sistem value chain prospek pengumpulan ewaste di bank sampah dibagi menjadi beberapa aktivitas primer yaitu inbound logistics, operations, outbound logistics, dan marketing (Porter, 1998). Informasi dalam sistem value chain ini diperoleh berdasarkan hasil wawancara. Unitunit bisnis atau stakeholders yang terdapat dalam value chain management sebagai berikut:
- Masyarakat

- Bank Sampah

- Yayasan Bank Sampah Bunga Melati Bersih

- Pool Bank Sampah

- Forum Komunikasi Bank Sampah

- Bank Sampah Induk

- Lapak

- Forum Komunikasi Lapak

- DKP (Dinas Kebersihan dan Pertamanan)

- BLHD (Badan Lingkungan Hidup Daerah)

- Industri Pengolah Limbah Elektronik

- CSR Industri

Inbound logistics yang merupakan aktivitas awal dari value chain management bermula dari masyarakat yang melakukan pengumpulan dan pemilahan sampah. Apabila belum terdaftar sebagai nasabah bank sampah, masyarakat tersebut harus mengisi formulir data nasabah di bank sampah (business unit). Lalu, pihak bank sampah akan membuatkan profil data nasabah $( \pm 5$ menit).

Kemudian pada aktivitas primer operations, masyarakat menyetorkan sampah yang telah dikumpulkan sekaligus dilakukan penimbangan oleh pihak bank sampah (2 minggu sekali). Lalu, dilakukan pencatatan dan update data pada buku tabungan dengan waktu \pm 5 menit. Selain penyetoran sampah secara umum, dapat dibuat event khusus untuk mengumpulkan e-waste yang lebih banyak. Hal ini dapat dilakukan 1 atau 2 bulan sekali. Event khusus ini dapat digolongkan dalam aktivitas primer marketing.

Setelah itu masuk pada aktivitas outbound logistics, yaitu dilakukan pengangkutan dan pengiriman sampah menuju 2 business unit yaitu pihak pool bank sampah dan pihak lapak. Pengangkutan sampah elektronik oleh pool dilakukan setiap 2 bulan sekali dengan menggunakan motor bak sampah. Setelah e-waste telah terkumpul di masing-masing pool, akan dilakukan pengangkutan sampah oleh industri pengangkut dan pengolah $e$-waste (business unit) mengelilingi pool bank sampah yang ada dengan menggunakan dump truck (kapasitas: $8.000 \mathrm{~kg}$ ).

Hasil rakornas bank sampah ke-3 di Makassar berimplikasi terhadap adanya keterlibatan bank sampah induk di pusat kota Tangerang Selatan dalam proses pengangkutan sampah elektronik dari pool bank sampah menuju industri pengangkut dan pengolah sampah elektronik. Skenario 2 ini ditunjukan dengan garis hijau dalam sistem value chain. Proses pengangkutan sampah elektronik dimulai dari bank sampah induk yang mengelilingi pool bank sampah menggunakan mini truck. Untuk sampah-sampah non 
e-waste akan diangkut oleh pihak lapak dari masing-masing bank sampah. Selain aktivitas primer, terdapat pula aktivitas pendukung seperti procurement yaitu aktivitas pembelian sampah elektronik. Terdapat pertukaran arus informasi antar stakeholder berupa saran, keluhan, ataupun update data.

Pembuatan value chain juga dilengkapi dengan adanya SWOT terhadap sistem yang telah dirancang. Dari segi strength, mayoritas kekuatan sistem value chain ini terdapat pada aktivitas outbound logistics seperti penentuan rute transportasi pengangkutan e-waste berdasarkan rute terpendek dan implementasi sistem pool bank sampah sebagai sistem pengangkutan yang terintegrasi. Kemudian nilai positif pada aktivitas marketing, terdapat event khusus untuk pengumpulan $e$-waste yang memberikan insentif pada masyarakat seperti lomba berhadiah dan doorprize. Kemudian aliran informasi yang saling terintegrasi antar stakeholder dalam sistem value chain juga menjadi karakteristik positif. Kemudian, kelemahan dari sistem ini juga terdapat pada aktivitas outbound logistics yaitu lokasi industri pengolah $e$-waste yang cukup jauh yaitu di Majalengka, sedangkan bank-bank sampah terdapat di Tangerang Selatan. Lalu, belum dapat dibedakan antara lapak yang sehat ataupun yang tidak karena indikator belum terkuantifikasi, belum ada peraturan pemerintah atau daerah yang secara khusus mengatur pengumpulan e-waste, dan kurangnya pengetahuan masyarakat akan $e$-waste dan bank sampah.

Dari aspek kesempatan, terdapat kesempatan untuk memperluas cakupan pengangkutan $e$ waste ke daerah sekitarnya. Ancaman dari eksternal juga dapat muncul seperti adanya potensi kemacetan dalam proses pengangkutan e-waste. Selain itu, adanya sektor informal (penadah/lapak) yang mengumpulkan e-waste juga merupakan ancaman eksternal. Strategi yang diperlukan untuk menanganinya ialah adanya koordinasi dan komitmen antar stakeholder sehingga tercipta sinergi dalam pengumpulan $e$ waste di bank sampah.

\subsection{Deskripsi Causal Loop Diagram}

Pendekatan causal loop diagram diterapkan sebagai tool yang sangat penting dalam merepresentasikan struktur feedback dalam suatu sistem (Sterman, 2000). Terdapat 2 skenario pada causal loop diagram yang dirancang yaitu skenario 1 : tanpa bank sampah induk dan skenario 2: dengan bank sampah induk.

Causal loop diagram skenario 1 ini dimulai dari adanya peraturan PP No. 81 Tahun 2012 dan UU No. 18 Tahun 2008 tentang pengelolaan sampah. Dengan adanya peraturan ini, pemerintah memiliki tanggung jawab dalam mensosialisasikan perihal pengumpulan sampah sehingga berefek positif terhadap kesadaran masyarakat untuk mengumpulkan sampah. Tingkat pengumpulan sampah juga dipengaruhi oleh faktor jumlah barang usang yang dihasilkan.

Apabila jumlah sampah yang dikumpulkan tidak sesuai dengan jumlah sampah yang diinginkan maka akan timbul gap sampah. Gap ini akan berimplikasi positif kembali terhadap sosialisasi pemerintah tentang pengelolaan sampah dan terhadap insentif yang diberikan. Insentif akan berdampak langsung terhadap minat keterlibatan RT dalam pengelolaan sampah. Hal ini tergolong dalam model dengan tipe perilaku goal-seeking.

Dari tingkat pengumpulan sampah, akan dilihat seberapa banyak tingkat setoran ke bank sampah. Tingkat setoran ke bank sampah ini dipengaruhi oleh adanya peraturan pemerintah yaitu Permen LH No. 13 Tahun 2012, dari komunikasi mulut ke mulut, dan media / kampanye. Setoran sampah pada bank sampah akan dipilah menjadi 2 yaitu e-waste dan non e-waste.

Jika setoran sampah tidak sesuai dengan jumlah setoran sampah yang diinginkan, maka akan muncul gap sampah yang dikumpulkan di bank sampah. Jika gap yang muncul besar, maka iklan lewat media, Permen LH No. 13 tahun 2012, dan mouth-to-mouth harus semakin diperkuat.

Lalu, sampah elektronik akan dibagi lagi menjadi 2 kategori berdasarkan beratnya menjadi gadget, small and medium e-waste dan big e-waste seperti terlihat pada Gambar 6. Selanjutnya, sampah elektronik gadget, kecil dan sedang diangkut ke pool bank sampah di masing-masing kecamatan. Kemudian, industri pengolah sampah elektronik akan mengangkut sampahsampah elektronik tersebut dari masing-masing pool yang ada. Untuk sampah non e-waste akan diangkut menuju pihak lapak.

Kemudian setelah e-waste sampai pada industri pengolah sampah elektronik, dilakukan pemilahan antara e-waste dengan kategori gadget, small appliances, dan medium appliances yang terkumpul. Lalu dilakukan pembongkaran $e$ waste sehingga didapat material berharga. Maka dapat diketahui profit dari proses daur ulang $e$ waste di masing-masing kategori. Total recycling profit semua kategori e-waste ini akan dikurangi dengan total biaya sehingga didapat total keuntungan yang diperoleh pihak industri.

Pada skenario yang berbeda, terdapat adanya 


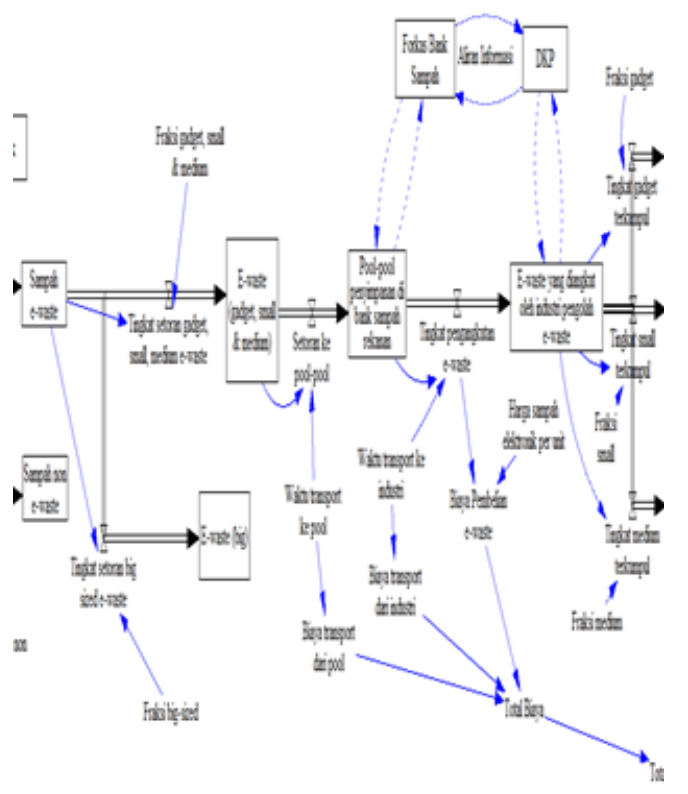

Gambar 6: Causal loop diagram Skenario 1

keterlibatan bank sampah induk. Mekanisme awal causal loop diagram skenario 2 ini sama dengan mekanisme awal causal loop diagram skenario 1. Pada bagian tengah proses seperti terlihat pada Gambar 7, sampah elektronik yang telah dikumpulkan sebelumnya akan diangkut ke pool bank sampah, sebelum akhirnya diangkut menuju bank sampah induk. Begitu juga dengan big e-waste dan sampah non e-waste yang juga dikirimkan menuju bank sampah induk. Di bank sampah induk, sampah dengan kategori gadget, small appliances, dan medium appliances akan dikirim menuju industri pengolah limbah elektronik, sedangkan sampah non e-waste akan diangkut menuju pihak lapak. Mekanisme akhir pada skenario 2 ini juga sama dengan mekanisme akhir pada skenario 1 .

\section{Simulasi}

Bagian ini berisi parameter simulasi, simulasi skenario 1 dan 2, perhitungan biaya dan pendapatan proses daur ulang seluruh komponen e-waste dan komponen PCB saja.

\subsection{Parameter Simulasi untuk Pem- belian E-waste}

Dalam perancangan simulasi, ditambahkan beberapa parameter untuk biaya pembelian $e$ waste dari bank sampah. Parameter ini diperlukan untuk menyesuaikan simulasi dengan berbagai kondisi yang mungkin terjadi pada

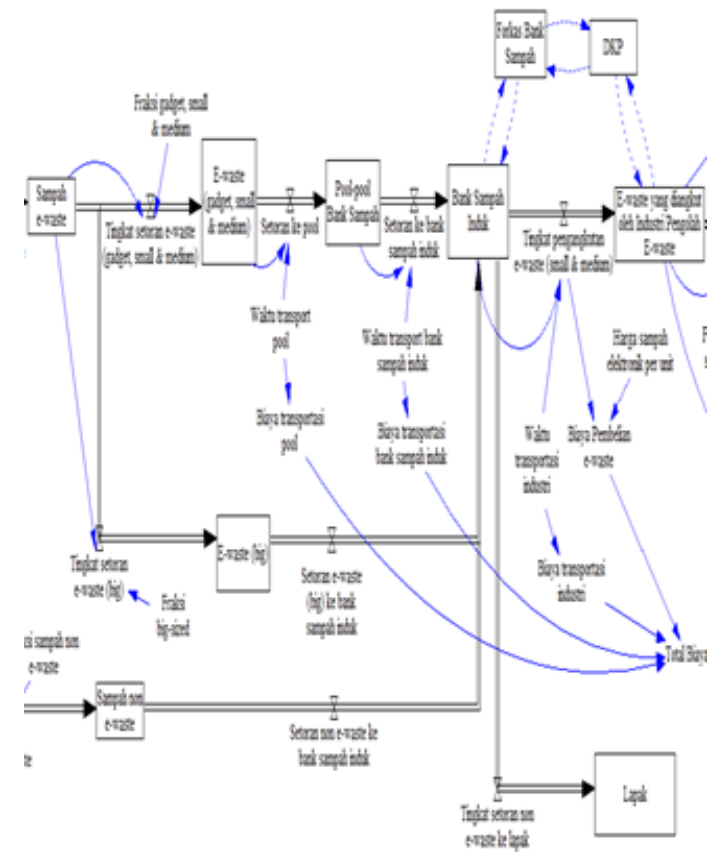

Gambar 7: Causal loop diagram Skenario 2

saat proses pengangkutan $e$-waste. Berbagai parameter simulasi untuk pembelian $e$-waste yaitu:

- Tipe motor (kapasitas) : Motor bak sampah dengan kapasitas 200 kg, 300 kg, 400 kg, dan $500 \mathrm{~kg}$

- Rute perjalanan : seusai dengan perhitungan rute terpendek menggunakan metode saving dalam traveling salesman problem

- Persentase muatan sampah elektronik per motor bak sampah:

- Kondisi pesimis : $50 \%$ full

- Kondisi netral : 70\% full

- Kondisi optimis 90\% full

- Frekuensi perjalanan : 2 bulan / perjalanan

Setelah ditentukan berbagai parameter yang digunakan dalam simulasi, selanjutnya akan dikalkulasi biaya pembelian e-waste berdasarkan parameter simulasi. Data tambahan berupa data volume $e$-waste tahun 2015 dibutuhkan untuk mengklasifikasikan masing-masing jenis ewaste ke dalam kategori e-waste. Akan didapatkan hasil seperti pada Tabel 3. Persentase ini akan digunakan untuk menentukan banyaknya unit masing-masing kategori e-waste dalam motor bak sampah.

Selain data jumlah volume sampah elektronik, data berat masing-masing jenis sampah elektronik yang didapat dari tabel 4 diperlukan dalam mengkonversi jumlah sampah elektronik dalam satuan kilogram menjadi satuan unit. 
Tabel 3: Pool Bank Sampah

\begin{tabular}{|l|c|c|}
\hline Kategori E-Waste & $\begin{array}{c}\text { Jumlah } \\
\text { (kiloton) }\end{array}$ & Persentase \\
\hline Gadget & 35,4 & $4,225 \%$ \\
\hline Small appliances & 332 & $39,675 \%$ \\
\hline Medium appliances & 470 & $56,099 \%$ \\
\hline
\end{tabular}

Sumber : Cucchiella, et al. (2015)

Tabel 4: Pool Bank Sampah

\begin{tabular}{|l|c|}
\hline Kategori E-Waste & Berat (kg) \\
\hline Gadget & 0,12 \\
\hline Small appliances & 3,5 \\
\hline Medium appliances & 25 \\
\hline \multicolumn{2}{|l|}{ Sumber : Cucchiella, et al. (2015) }
\end{tabular}

Tabel 5 menunjukan rangkuman biaya pembelian e-waste untuk seluruh pool bank sampah. Perhitungan biaya pembelian e-waste didapat menggunakan data persentase kategori e-waste di motor bak sampah (Tabel 3), data berat $e$ waste (Tabel 4) dan harga masing-masing e-waste dimana gadget dan small appliances dihargai $\mathrm{Rp}$. 5.000 dan medium appliances dihargai Rp. 25.000.

Tabel 5: Rangkuman Biaya Pembelian E-waste untuk Seluruh Pool Bank Sampah

\begin{tabular}{|c|c|c|c|}
\hline \multirow{2}{*}{$\begin{array}{c}\text { Kapasitas } \\
\mathbf{( k g )}\end{array}$} & \multicolumn{3}{|c|}{ Biaya Pembelian $\boldsymbol{E}$-Waste (Rp) } \\
\cline { 2 - 4 } & Pesimis & Netral & Optimis \\
\hline 200 & 1.400 .000 & 2.000 .000 & 2.575 .000 \\
\hline 300 & 2.125 .000 & 3.075 .000 & 3.900 .000 \\
\hline 400 & 2.825 .000 & 4.025 .000 & 5.200 .000 \\
\hline 500 & 3.650 .000 & 5.075 .000 & 6.475 .000 \\
\hline
\end{tabular}

\subsection{Simulasi Skenario 1: Pool Bank Sampah Industri Pengolah E- waste}

Pengumpulan sampah elektronik pada skenario ini dimulai dari sampah elektonik yang dikumpulkan di bank sampah akan diangkut ke pool-pool bank sampah dengan menggunakan motor bak sampah. Setelah terkumpul, pihak industri pengolah limbah elektronik akan mengangkut tumpukan sampah elektronik dengan menggunakan truk. Mekanisme pengumpulan sampah elektronik di bank sampah setempat dapat dilakukan dengan diadakannya event setiap 2 bulan sekali.

Adapun total biaya skenario 1 dapat dihitung dengan menggunakan rumus:

$$
C_{1}=C_{b}+C_{t 1}
$$

dimana

$$
\begin{gathered}
C_{b}=C_{g}+C_{s}+C_{m} \\
C_{t 1}=C_{m o}+C_{d t r}
\end{gathered}
$$

Keterangan :

$C_{1}=$ total biaya skenario 1

$C_{b}=$ biaya pembelian $e$-waste

$C_{g}=$ biaya pembelian gadget

$C_{s}=$ biaya pembelian small appliances

$C_{m}=$ biaya pembelian medium appliances

$C_{t 1}=$ biaya transportasi skenario 1

$\mathrm{Cmo}=$ biaya transportasi motor bak sampah

$C_{d t r}=$ biaya transportasi dump truck

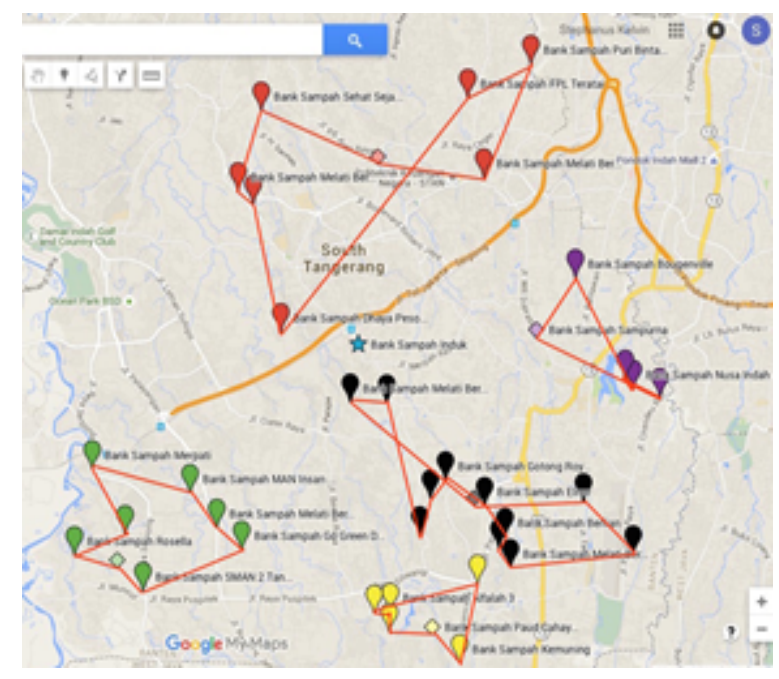

Gambar 8: Rute Proses Pengangkutan Sampah Elektronik Skenario 1

Gambar 8 menunjukan rute proses pengangkutan sampah elektronik pada skenario 1. Garis berwarna merah menandakan rute transportasi motor bak sampah yang ditentukan berdasarkan rute terpendek menggunakan metode saving dalam teori vehicle routing problem.

Dalam melakukan pengangkutan sampah menuju pool bank sampah di masing-masing kecamatan, motor bak sampah mengkuti jalur terpendek. Data biaya transportasi pada berbagai kecamatan dapat dilihat pada Tabel 6. Perhitungan menggunakan data konsumsi BBM motor bak sampah yaitu $27 \mathrm{~km} /$ liter dan asumsi harga bensin premium yaitu Rp. 7.300 per Oktober 2015.

Total biaya pada seluruh pool bank sampah kota Tangerang Selatan dapat dilihat pada Tabel 7. Total biaya seluruh pool didapat dengan menjumlahkan biaya transportasi motor dan harga sampah elektronik di masing-masing kecamatan. 
Tabel 6: Biaya Transportasi Motor Bak Sampah

\begin{tabular}{|c|c|c|c|}
\hline Kecamatan & $\begin{array}{c}\text { Total } \\
\text { Jarak } \\
\text { (km) }\end{array}$ & $\begin{array}{c}\text { Konsumsi } \\
\text { BBM } \\
\text { (liter) }\end{array}$ & $\begin{array}{c}\text { Biaya } \\
\text { Transport } \\
\text {-asi (Rp.) }\end{array}$ \\
\hline Pondok Aren & 28,45 & 1,054 & 7.693 \\
\hline Setu dan Serpong & 17 & 0,630 & 4.596 \\
\hline Ciputat Timur & 13,43 & 0,497 & 3.63 \\
\hline Pamulang 1 & 28,05 & 1,039 & 7.583 \\
\hline Pamulang 2 & 7,92 & 0,293 & 2.141 \\
\hline \multicolumn{2}{|c|}{ TOTAL } & $\mathbf{2 5 . 6 4 4}$ \\
\hline
\end{tabular}

Tabel 7: Rangkuman Biaya Pembelian E-waste untuk Seluruh Pool Bank Sampah

\begin{tabular}{|c|c|c|c|}
\hline \multirow{2}{*}{$\begin{array}{c}\text { Kapasitas } \\
\text { (kg) }\end{array}$} & \multicolumn{3}{|c|}{ Total Biaya Pool (Rp) } \\
\cline { 2 - 4 } & Pesimis & Netral & Optimis \\
\hline 200 & 1.425 .644 & 2.025 .644 & 2.600 .644 \\
\hline 300 & 2.150 .644 & 3.100 .644 & 3.925 .644 \\
\hline 400 & 2.850 .644 & 4.050 .644 & 5.225 .644 \\
\hline 500 & 3.675 .644 & 5.100 .644 & 6.500 .644 \\
\hline
\end{tabular}

Setelah e-waste dari masing-masing bank sampah diangkut menuju pool-pool bank sampah, selanjutnya pihak industri pengelola limbah elektronik akan mengangkut kumpulan sampah di masing-masing pool bank sampah berdasarkan rute terpendek yaitu mulai dari industri pengelola limbah elektronik bank sampah sampurna bank sampah asyainiyah bank sampah melati bersih armapura bank sampah paud cahaya agung dan berakhir di bank sampah asri mandiri, lalu kembali ke industri pengelola limbah elektronik.

Biaya transportasi dump truck oleh industri pengolah e-waste terlihat pada Tabel 8 . Konsumsi BBM didapat dengan membagi total jarak (441 km) dengan asumsi konsumsi BBM dump truck yaitu sebesar $3,8 \mathrm{~km} /$ liter. Biaya transportasi truk didapat dengan mengalikan konsumsi BBM dengan harga solar yaitu Rp. 6.700 per Oktober 2015 sehingga didapat biaya transportasi truk.

Total keseluruhan biaya yang harus ditanggung dalam skenario ini $\left(C_{1}\right)$ didapat dengan menambahkan biaya transportasi truk dengan total biaya seluruh pool bank sampah pada Tabel 7. Hasil dapat dilihat pada Tabel 9.

Tabel 8: Biaya Transportasi Truk oleh Industri Pengolah Limbah Elektronik

\begin{tabular}{|c|c|c|c|}
\hline Rute & $\begin{array}{c}\text { Total) } \\
\text { Jarak } \\
\mathbf{( k m )}\end{array}$ & $\begin{array}{c}\text { Konsumsi } \\
\text { BBM } \\
\text { (Liter) }\end{array}$ & $\begin{array}{c}\text { Biaya } \\
\text { Transport } \\
\text { asi Truk) } \\
\text { (Rp.) }\end{array}$ \\
\hline $0-3-1-2-5-4-0$ & 441 & 116 & 777.553 \\
\hline
\end{tabular}

Tabel 9: Total Biaya Keseluruhan Skenario 1

\begin{tabular}{|c|c|c|c|}
\hline \multirow{2}{*}{$\begin{array}{c}\text { Kapasitas } \\
\mathbf{( k g})\end{array}$} & \multicolumn{3}{|c|}{ Total Biaya Skenario 1 (Rp.) } \\
\cline { 2 - 4 } & Pesimis & Netral & Optimis \\
\hline 200 & 2.203 .197 & 2.803 .197 & 3.378 .197 \\
\hline 300 & 2.928 .197 & 3.878 .197 & 4.703 .197 \\
\hline 400 & 3.628 .197 & 4.828 .197 & 6.003 .197 \\
\hline 500 & 4.453 .197 & 5.878 .197 & 7.278 .197 \\
\hline
\end{tabular}

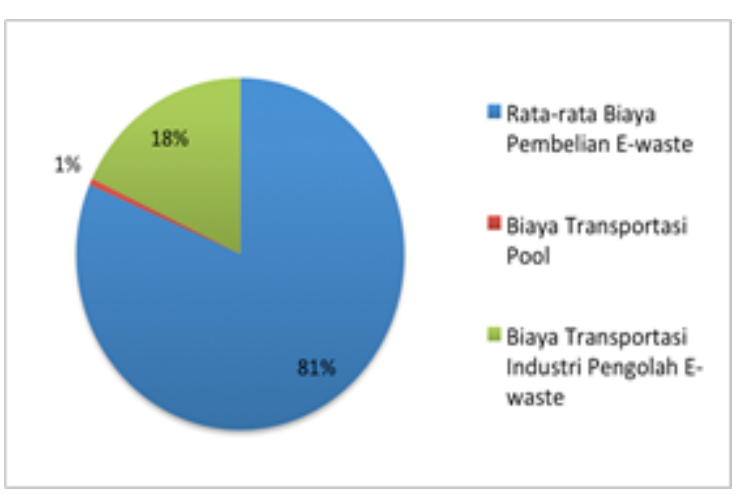

Gambar 9: Rute Proses Pengangkutan Sampah Elektronik Skenario 1

Gambar 9 menunjukan persentase biaya skenario 1. Mayoritas persentase biaya skenario ini didominasi oleh biaya pembelian e-waste dengan persentase sebesar $81 \%$ dari keseluruhan biaya yang harus ditanggung.

\subsection{Simulasi Skenario 2: Pool Bank Sampah Bank Sampah Induk In- dustri Pengolah E-waste}

Skenario ini merupakan skenario yang melibatkan baik pool bank sampah maupun bank sampah induk. Keberadaan bank sampah induk didasarkan pada hasil rapat koordinasi nasional bank sampah ke-3. Pada mekanisme skenario ini, sampah yang telah dikumpulkan di pool-pool bank sampah ini akan diangkut menuju bank sampah induk. Kemudian, pihak industri pengolah limbah elektronik akan mengangkut tumpukan sampah elektronik dengan menggunakan dump truck ke bank sampah induk. Lokasi bank sampah induk ditentukan agar berada di tengah-tengah atau pusat kota sehingga bank sampah yang ada disekitarnya mudah dalam mencapainya.

Adapun total biaya pada skenario 2 dapat dihitung dengan menggunakan rumus:

$$
C_{2}=C_{b}+C_{t 2}
$$

dimana

$$
C_{b}=C_{g}+C_{s}+C_{m}
$$




$$
C_{t 2}=C_{m o}+C_{m t r}+C_{d t r}
$$

Keterangan :

$C_{2}=$ total biaya skenario 2

$C_{t 2}=$ biaya transportasi skenario 2

$C_{m t r}=$ biaya transportasi mini truck

Mekanisme awal pada skenario ini sama seperti dengan mekansime awal pada skenario sebelumnya sehingga menghasilkan total biaya yang serupa. Setelah proses ini selesai, maka akan timbul biaya pengangkutan dengan menggunakan mini truck $\left(C_{m t r}\right)$ dari masing-masing pool bank sampah menuju bank sampah induk yang telah ditentukan lokasinya.

Dengan rute yang telah dibuat, maka diketahui total jarak yang harus ditempuh ialah 47 $\mathrm{km}$ sehingga total biaya yang harus ditanggung $\left(C_{m t r}\right)$ ialah Rp. 44.986. Asumsi yang digunakan ialah rata-rata konsumsi BBM mini truck adalah $7 \mathrm{~km} /$ liter atau 0,143 liter $/ \mathrm{km}$. Hal ini dapat dilihat pada Tabel 10.

Tabel 10: Biaya Transportasi Truk oleh Industri Pengolah Limbah Elektronik

\begin{tabular}{|c|c|c|c|c|}
\hline $\begin{array}{c}\text { Total } \\
\text { Jarak } \\
(\mathbf{k m})\end{array}$ & $\begin{array}{c}\text { Rata-rata } \\
\text { Konsum- } \\
\text { si BBM } \\
\text { (liter/km) }\end{array}$ & $\begin{array}{c}\text { Konsumsi } \\
\text { BBM } \\
\text { (liter) }\end{array}$ & $\begin{array}{c}\text { Harga } \\
\text { solar } \\
\text { (Rp./liter) }\end{array}$ & $\begin{array}{c}\text { Total } \\
\text { Biaya } \\
\text { (Rp.) }\end{array}$ \\
\hline 47 & 0,143 & 6,714 & 6.7 & 44.986 \\
\hline
\end{tabular}

Gambar 10 menunjukan rute proses pengangkutan sampah elektronik pada skenario 2 yang ditentukan menggunakan metode saving dalam vehicle routing problem. Garis berwarna merah menandakan rute transportasi motor bak sampah dimana pada rute tersebut muncul berbagai biaya seperti $C_{b}$ dan $C_{m o}$. Selain itu, juga muncul biaya transportasi mini truck $\left(C_{m} t r\right)$ dari bank sampah induk mengelilingi pool bank sampah yang ditandai dengan garis biru.

Setelah total biaya seluruh pool pada Tabel 8 ditambah dengan biaya transportasi pengangkutan ke bank sampah induk $\left(C_{m t r}\right)$ sebesar Rp. 44.986, maka didapatkan hasil pada Tabel 11.

Kemudian hasil pada Tabel 11 ditambahkan dengan biaya tranportasi dump truck dari pihak industri menuju bank sampah induk. Rincian biaya dapat dilihat pada Tabel 12 dimana jarak yang harus ditempuh menuju bank sampah induk sebesar $211 \mathrm{~km}$. Rata-rata konsumsi BBM dump truck itu sebesar 3,8 km/liter. Asumsi harga solar per Oktober 2015 ialah Rp. 6.700.

Total keseluruhan biaya dengan skenario bank sampah induk $\left(C_{2}\right)$ ini didapat dengan

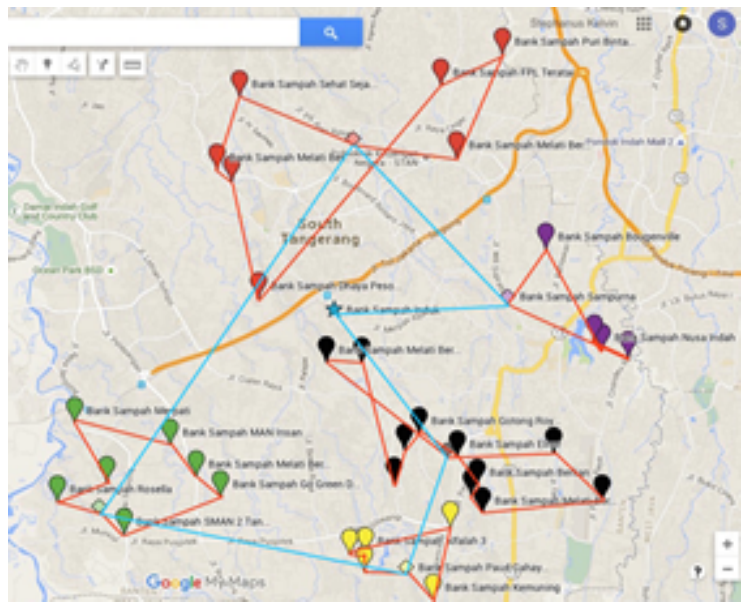

Gambar 10: Rute Proses Pengangkutan Sampah Elektronik Skenario 2

Tabel 11: Biaya Transportasi Mini Truck dan Motor serta Pembelian E-waste

\begin{tabular}{|c|c|c|c|}
\hline Kapasitas & \multicolumn{3}{|l}{$\begin{array}{l}\text { Biaya } \\
\text { Sampah Induk (Rp.) }\end{array}$} \\
\cline { 2 - 4 }$(\mathbf{k g})$ & Pesimis & Netral & Optimis \\
\hline 200 & 1.470 .630 & 2.070 .630 & 2.645 .630 \\
\hline 300 & 2.195 .630 & 3.145 .630 & 3.970 .630 \\
\hline 400 & 2.895 .630 & 4.095 .630 & 5.270 .630 \\
\hline 500 & 3.720 .630 & 5.145 .630 & 6.545 .630 \\
\hline
\end{tabular}

menambahakan biaya pada Tabel 11 dengan biaya transportasi dump truck sebesar Rp. 744.053. Hasil ini dapat dilihat pada Tabel 13.

Gambar 11 menunjukan persentase biaya skenario 2. Mayoritas persentase biaya skenario ini didominasi oleh biaya pembelian e-waste dengan persentase sebesar $81 \%$ dari keseluruhan biaya yang harus ditanggung.

\subsection{Perhitungan Recycling Cost dan Potential Revenue dari Seluruh Komponen E-waste}

Setelah didapatkan hasil total biaya (biaya transportasi dan biaya pembelian e-waste) pada skenario 1 dan skenario 2, keuntungan yang akan didapatkan pihak industri pengolah e-waste juga harus diperhitungkan dengan mempertimbangkan biaya dan pendapatan yang diperoleh

Tabel 12: Biaya Transportasi Dump Truck

\begin{tabular}{|c|c|c|c|}
\hline $\begin{array}{c}\text { Total } \\
\text { Jarak } \\
(\mathbf{k m})\end{array}$ & $\begin{array}{c}\text { Konsumsi } \\
\text { BBM } \\
\text { (liter) }\end{array}$ & $\begin{array}{c}\text { Total } \\
\text { Biaya } \\
\text { (Rp.) }\end{array}$ & $\begin{array}{c}\text { Total Biaya } \\
\text { Bolak-Balik } \\
\text { (Rp.) }\end{array}$ \\
\hline 211 & 55,53 & 372.026 & 744.053 \\
\hline
\end{tabular}


Tabel 13: Total Biaya Keseluruhan Skenario 2

\begin{tabular}{|c|c|c|c|}
\hline \multirow{2}{*}{$\begin{array}{c}\text { Kapasitas } \\
\text { (kg) }\end{array}$} & \multicolumn{3}{|c|}{ Total Biaya Skenario 2 (Rp.) } \\
\cline { 2 - 4 } & Pesimis & Netral & Optimis \\
\hline 200 & 2.214 .682 & 2.814 .682 & 3.389 .682 \\
\hline 300 & 2.939 .682 & 3.889 .682 & 4.714 .682 \\
\hline 400 & 3.639 .682 & 4.839 .682 & 6.014 .682 \\
\hline 500 & 4.464 .682 & 5.889 .682 & 7.289 .682 \\
\hline
\end{tabular}

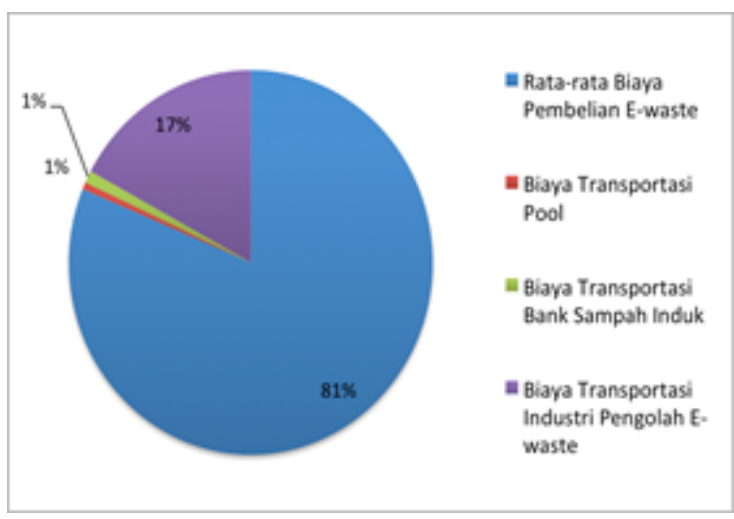

Gambar 11: Persentase Biaya Skenario 2

apabila mendaur ulang seluruh komponen sampah elektronik. Tabel 14 menunjukan biaya dan pendapatan proses daur ulang yang telah dikonversi menjadi mata uang rupiah untuk masingmasing kategori.

Rangkuman jumlah e-waste seperti terlihat pada Tabel 15 dibutuhkan dalam perhitungan profit proses daur ulang. Jumlah unit e-waste pada Tabel 15 merupakan jumlah $e$-waste yang ada pada 5 pool bank sampah.

Setelah dilakukan perhitungan profit proses daur ulang seluruh komponen sampah elektronik, maka dilakukan perhitungan untuk mengetahui keuntungan keseluruhan pada masing-masing skenario. Tabel 16 menunjukan rangkuman profit proses recycling pada

Tabel 14: Biaya dan Pendapatan Proses Daur Ulang Seluruh Komponen E-waste dalam Rupiah

\begin{tabular}{|c|c|c|}
\hline $\begin{array}{c}\text { Tipe } \\
\text { e-waste }\end{array}$ & $\begin{array}{c}\text { Average } \\
\text { Recycling } \\
\text { Cost } \\
\text { (Rp. / unit) }\end{array}$ & $\begin{array}{c}\text { Average } \\
\text { Potential } \\
\text { Revenue } \\
\text { (Rp. / unit) }\end{array}$ \\
\hline Gadget & $2.464^{*}$ & $10.268^{*}$ \\
\hline Small appliances & $41.070^{* *}$ & $163.413^{* * *}$ \\
\hline Medium appliances & $54.760^{* *}$ & $262.024^{* * *}$ \\
\hline
\end{tabular}

${ }^{*}$ Geyer dan Blass (2010)

**CalRecycle (2015)

${ }^{* * *}$ Cucchiella, et al. (2015)
Tabel 15: E-waste untuk 5 Pool Bank Sampah

\begin{tabular}{|c|c|c|c|}
\hline \multirow[t]{2}{*}{$\begin{array}{l}\text { Kategori } \\
\text { e-waste }\end{array}$} & \multicolumn{3}{|c|}{$\begin{array}{l}\text { Jumlah E-waste [Kapasitas (200 } \\
\text { kg)] }\end{array}$} \\
\hline & Pesimis & Netral & Optimis \\
\hline Gadget & 175 & 245 & 315 \\
\hline Small & 55 & 80 & 100 \\
\hline Medium & 10 & 15 & 20 \\
\hline \multirow[t]{2}{*}{$\begin{array}{l}\text { Kategori } \\
\text { e-waste }\end{array}$} & \multicolumn{3}{|c|}{$\begin{array}{l}\text { Jumlah E-waste [Kapasitas (300 } \\
\text { kg)] }\end{array}$} \\
\hline & Pesimis & Netral & Optimis \\
\hline Gadget & 265 & 370 & 475 \\
\hline Small & 85 & 120 & 155 \\
\hline Medium & 15 & 25 & 30 \\
\hline \multirow[t]{2}{*}{$\begin{array}{l}\text { Kategori } \\
\text { e-waste }\end{array}$} & \multicolumn{3}{|c|}{$\begin{array}{l}\text { Jumlah E-waste [Kapasitas (400 } \\
\text { kg)] }\end{array}$} \\
\hline & Pesimis & Netral & Optimis \\
\hline Gadget & 350 & 495 & 635 \\
\hline Small & 115 & 160 & 205 \\
\hline Medium & 20 & 30 & 40 \\
\hline \multirow[t]{2}{*}{$\begin{array}{l}\text { Kategori } \\
\text { e-waste }\end{array}$} & \multicolumn{3}{|c|}{$\begin{array}{l}\text { Jumlah E-waste [Kapasitas (500 } \\
\text { kg)] }\end{array}$} \\
\hline & Pesimis & Netral & Optimis \\
\hline Gadget & 440 & 615 & 790 \\
\hline Small & 140 & 200 & 255 \\
\hline Medium & 30 & 40 & 50 \\
\hline
\end{tabular}

*Satuan:unit

Tabel 16: Rangkuman Recycling Profit Seluruh Komponen E-waste

\begin{tabular}{|c|c|c|c|}
\hline \multirow{2}{*}{$\begin{array}{c}\text { Kapasitas } \\
\text { (kg) }\end{array}$} & \multicolumn{3}{|c|}{ Profit Proses Recyling (Rp.) } \\
\cline { 2 - 4 } & Pesimis & Netral & Optimis \\
\hline 200 & 10.167 .076 & 14.808 .199 & 18.837 .608 \\
\hline 300 & 15.575 .980 & 22.749 .968 & 28.887 .635 \\
\hline 400 & 20.945 .867 & 29.655 .415 & 38.325 .947 \\
\hline 500 & 26.779 .377 & 37.558 .167 & 47.725 .243 \\
\hline
\end{tabular}

masing-masing kapasitas dan kondisi muatan.

Untuk mencari keuntungan yang didapat pada skenario 1, maka hasil pada Tabel 16 berupa profit proses daur ulang seluruh komponen $e$-waste harus dikurangi pada total biaya pada skenario 1 yang terdapat pada Tabel 9 sehingga didapatkan hasil keuntungan skenario 1 pada Tabel 17.

Sedangkan untuk mencari keuntungan yang didapat pada skenario 2, maka hasil pada Tabel 16 berupa profit proses daur ulang harus dikurangi pada total biaya pada skenario 2 yang terdapat pada Tabel 13 sehingga didapatkan hasil keuntungan skenario 2 pada Tabel 18. 
Tabel 17: Keuntungan Skenario 1

\begin{tabular}{|c|c|c|c|}
\hline \multirow{2}{*}{$\begin{array}{c}\text { Kapasitas } \\
\text { (kg) }\end{array}$} & \multicolumn{3}{|c|}{ Keuntungan Skenario 1 (Rp.) } \\
\cline { 2 - 4 } & Pesimis & Netral & Optimis \\
\hline 200 & 7.963 .879 & 12.005 .003 & 15.459 .412 \\
\hline 300 & 12.647 .783 & 18.871 .771 & 24.184 .438 \\
\hline 400 & 17.317 .670 & 24.827 .218 & 32.322 .751 \\
\hline 500 & 22.326 .180 & 31.679 .970 & 40.447 .047 \\
\hline
\end{tabular}

Tabel 18: Keuntungan Skenario 2

\begin{tabular}{|c|c|c|c|}
\hline \multirow{2}{*}{$\begin{array}{c}\text { Kapasitas } \\
\text { (kg) }\end{array}$} & \multicolumn{3}{|c|}{ Keuntungan Skenario 2 (Rp.) } \\
\cline { 2 - 4 } & Pesimis & Netral & Optimis \\
\hline 200 & 7.952 .394 & 11.993 .517 & 15.447 .926 \\
\hline 300 & 12.636 .297 & 18.860 .285 & 24.172 .953 \\
\hline 400 & 17.306 .184 & 24.815 .733 & 32.311 .265 \\
\hline
\end{tabular}

\subsection{Keuntungan Proses Daur Ulang PCB}

Setelah mengetahui keuntungan dari proses daur ulang apabila seluruh komponen $e$-waste dapat diproses, selanjutnya akan dikalkulasi keuntungan yang diperoleh pihak industri pengolah sampah elektronik apabila hanya komponen pcb (printed circuit board) dari e-waste yang dapat didaur ulang. Berikut persentase jumlah komponen PCB dari masing-masing kategori $e^{-}$ waste yang telah dikumpulkan:

- Gadget: 14\% (Waste \& Resources Action Programme, 2009)

- Small appliances: 13\% (Waste \& Resources Action Programme, 2009)

- Medium appliances : 3\% (Dalrymple, et al. 2007)

Persentase bobot PCB pada kategori gadget ditaksir melalui persentase bobot PCB pada IT/telecoms devices dan persentase bobot PCB pada kategori small appliances diperkirakan melalui persentase bobot PCB pada small consumer equipment. Data pada Tabel 19 merupakan hasil olahan dari berbagai sumber.

Setelah PCB recycling profit pada semua kapasitas dan muatan dihitung maka hasil rangkumannya dapat terlihat pada Tabel 20.

Untuk mencari keuntungan keseluruhan melalui PCB yang didapat pada skenario 1, maka hasil pada Tabel 20 berupa profit proses daur ulang PCB harus dikurangi pada total biaya pada skenario 1 yang terdapat pada tabel 9 sehingga didapatkan hasil keuntungan PCB skenario 1 pada Tabel 21.

Sedangkan keuntungan melalui PCB yang didapat pada skenario 2 dapat dilihat pada Tabel 22. Hasil ini didapat melalui pengurangan pada Tabel 20 berupa profit proses daur ulang PCB
Tabel 19: Keuntungan Daur Ulang PCB E-waste

\begin{tabular}{|c|c|c|c|}
\hline $\begin{array}{c}\text { PCB } \\
\text { Profit }\end{array}$ & $\begin{array}{c}\text { Gadget } \\
\text { (Rp.) }\end{array}$ & $\begin{array}{c}\text { Small } \\
\text { appliances } \\
\text { (Rp.) }\end{array}$ & $\begin{array}{c}\text { Medium } \\
\text { appliances } \\
\text { (Rp.) }\end{array}$ \\
\hline Gold & 1.423 & 38.529 & 63.51 \\
\hline Pt, Pd, In & 889 & 24.074 & 39.682 \\
\hline Copper & 338 & 9.157 & 15.093 \\
\hline Aluminium & 103 & 2.791 & 4.6 \\
\hline $\begin{array}{c}\text { Lead (Pb) dan } \\
\text { tin (Sn) }\end{array}$ & 33 & 898 & 1.48 \\
\hline Silver & 49 & 1.329 & 2.191 \\
\hline Iron (Fe) & 1 & 24 & 39 \\
\hline Nickel & 68 & 1.855 & 3.057 \\
\hline Total (Rp.) & $\mathbf{2 . 9 0 4}$ & $\mathbf{7 8 . 6 5 6}$ & $\mathbf{1 2 9 . 6 5 3}$ \\
\hline
\end{tabular}

Sumber: Chatterjee (2012) dan Printed Circuit Industry Federation (2002)

Tabel 20: Rangkuman PCB Recycling Profit

\begin{tabular}{|c|c|c|c|}
\hline Kapasitas & \multicolumn{3}{|c|}{ Profit Proses Recyling PCB (Rp.) } \\
\cline { 2 - 4 }$(\mathbf{k g})$ & Pesimis & Netral & Optimis \\
\hline 200 & 2.893 .161 & 4.238 .076 & 5.395 .061 \\
\hline 300 & 4.434 .806 & 6.545 .446 & 8.281 .622 \\
\hline 400 & 5.974 .252 & 8.478 .352 & 10.980 .252 \\
\hline 500 & 7.702 .431 & 10.783 .522 & 13.676 .683 \\
\hline
\end{tabular}

dengan tabel 13 berupa total biaya pada skenario 2.

\subsection{Analisis Keuntungan Skenario 1 dan Skenario 2}

Apabila pihak industri pengolah sampah elektronik hanya mendaur ulang komponen PCB, masih didapat keuntungan baik skenario 1 maupun skenario 2 seperti terlihat pada Tabel 22 dan Tabel 23. Walaupun memperoleh keuntungan, tetapi keuntungan yang diperoleh mendaur ulang PCB tidak tergolong signifikan apabila dibandingkan dengan keuntungan yang diperoleh apabila mendaur ulang seluruh komponen yang terdapat pada e-waste. Hal ini terlihat pada Gambar 12.

Kurang signifikannya keuntungan dikarenakan rata-rata persentase komponen PCB dalam e-waste hanya sekitar $10 \%$ sehingga ke-

Tabel 21: Keuntungan PCB Skenario 1

\begin{tabular}{|c|c|c|c|}
\hline \multirow{2}{*}{$\begin{array}{c}\text { Kapasitas } \\
(\mathbf{k g})\end{array}$} & \multicolumn{3}{|c|}{ Keuntungan PCB Skenario 1 (Rp.) } \\
\cline { 2 - 4 } & Pesimis & Netral & Optimis \\
\hline 200 & 689.964 & 1.434 .879 & 2.016 .864 \\
\hline 300 & 1.506 .610 & 2.667 .249 & 3.578 .425 \\
\hline 400 & 2.346 .055 & 3.650 .155 & 4.977 .055 \\
\hline 500 & 3.249 .234 & 4.905 .325 & 6.398 .486 \\
\hline
\end{tabular}


Tabel 22: Keuntungan PCB Skenario 2

\begin{tabular}{|c|c|c|c|}
\hline \multirow{2}{*}{$\begin{array}{c}\text { Kapasitas } \\
(\mathbf{k g})\end{array}$} & \multicolumn{3}{|c|}{ Keuntungan PCB Skenario 2 (Rp.) } \\
\cline { 2 - 4 } & Pesimis & Netral & Optimis \\
\hline 200 & 678.478 & 1.423 .393 & 2.005 .379 \\
\hline 300 & 1.495 .124 & 2.655 .763 & 3.566 .939 \\
\hline 400 & 2.334 .569 & 3.638 .669 & 4.965 .570 \\
\hline 500 & 3.237 .748 & 4.893 .839 & 6.387 .000 \\
\hline
\end{tabular}

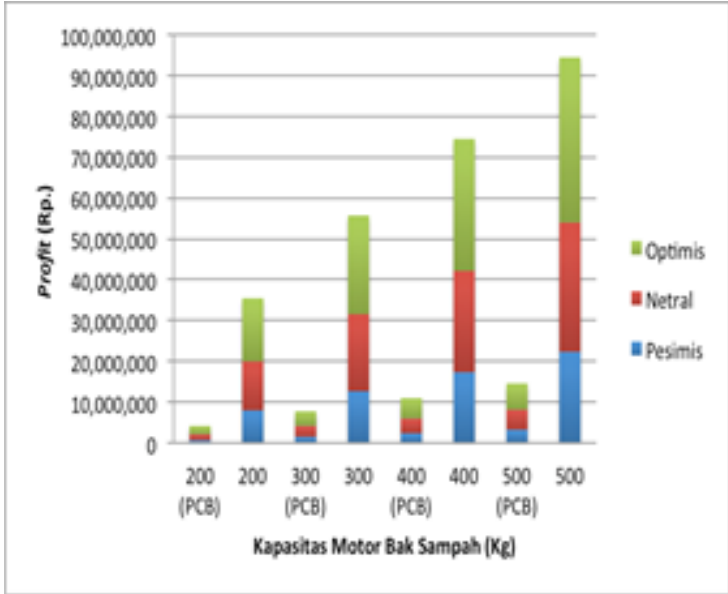

Gambar 12: Perbandingan Profit Skenario 1

untungan dari daur ulang PCB hanya memiliki persentase sebesar $28,63 \%$ dibandingkan dengan keuntungan dari mendaur ulang seluruh komponen yang terdapat pada e-waste. Persentase perbedaan ini akan semakin besar apabila dikalikan dengan banyaknya e-waste yang berhasil dikumpulkan sehingga menciptakan gap yang besar seperti terlihat pada Gambar 12 dan Gambar 13.

Kontribusi terbesar atas keuntungan proses daur ulang seluruh komponen e-waste pada berbagai kapasitas dan kondisi muatan ini ialah small appliances dengan $65 \%$. Hal ini dapat terli-

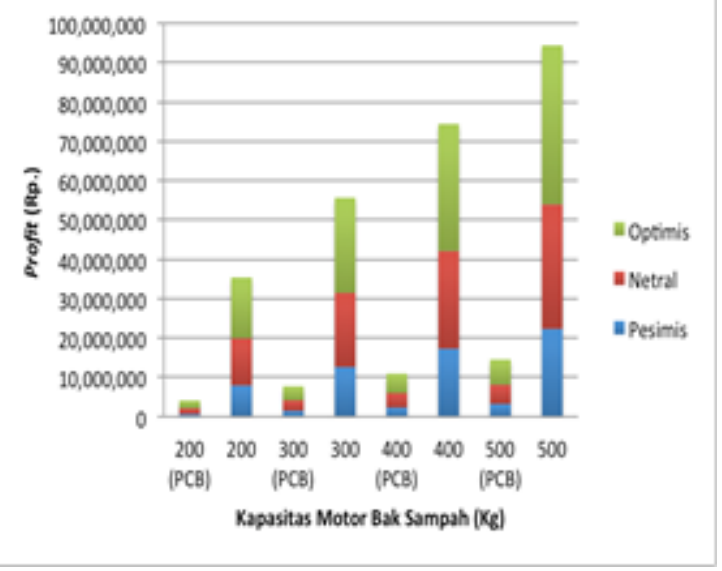

Gambar 13: Perbandingan Profit Skenario 2

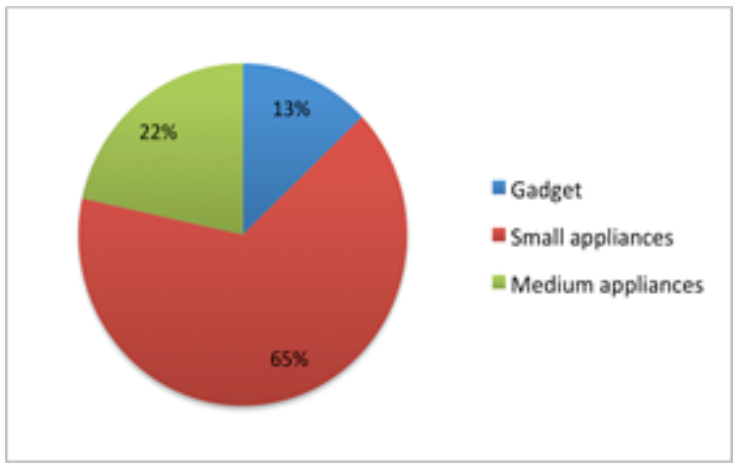

Gambar 14: Persentase Rata-rata Keuntungan Proses Daur ulang Seluruh Komponen E-waste

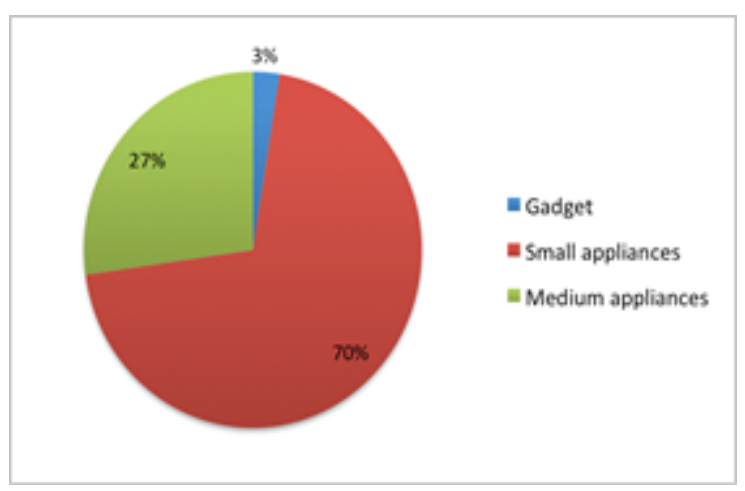

Gambar 15: Persentase Rata-rata Keuntungan Daur Ulang PCB

hat pada Gambar 14.

Kontribusi atas keuntungan proses daur ulang PCB pada berbagai kapasitas dan kondisi muatan dapat dilihat pada Gambar 15 dimana small appliances berkontribusi terbsesar yaitu $70 \%$, diikuti medium appliances $(27 \%)$, dan gadget (3\%).

\section{Kesimpulan dan Saran}

Adapun kesimpulan yang dapat diambil berdasarkan pengolahan data, analisis dan simulasi pada bagian sebelumnya ialah:

1. Sistem value chain prospek pengumpulan e-waste di bank sampah yang telah dirancang baik dalam bentuk value stream mapping maupun causal loop diagram pada 2 skenario yang berbeda melibatkan beberapa stakeholder seperti masyarakat, bank sampah, yayasan bank sampah, forum komunikasi bank sampah, pool-pool bank sampah, bank sampah induk, industri pengolah limbah elektronik, DKP, BLHD, CSR industri, lapak, dan forum komunikasi lapak. 
2. Penerapan sistem pool-pool bank sampah, penentuan rute terpendek, integrasi aliran informasi, dan adanya event khusus pengumpulan e-waste menjadi elemen krusial dan kekuatan dalam sistem value chain untuk meningkatkan nilai dan performa sistem secara keseluruhan sehingga keuntungan finansial dapat dimaksimalkan.

3. Berdasarkan hasil simulasi pengumpulan dan pengangkutan sampah dihasilkan keuntungan skenario 1 dengan rentang Rp. 7.963.879 - Rp. 40.447.047 dan keuntungan skenario 2 dengan rentang Rp. 7.952.394 40.435 .561 pada berbagai kapasitas motor bak sampah dan kondisi muatan sehingga proyek percontohan pengumpulan sampah elektronik profitable untuk dijalankan.

4. Kategori small appliances (LCD notebooks, LED notebooks, LCD monitors, LED monitors, dan HDD) berkontribusi sebesar 65\% terhadap total keuntungan dari proses daur ulang, disusul kategori medium appliances (CRT TV, LCD TV, LED TV, dan CRT monitors) dengan 22\%, dan gadget (cell phone, smart phone, dan tablet) yang berkontribusi sebesar $13 \%$.

5. Keuntungan daur ulang PCB pada skenario 1 dihasilkan dalam rentang Rp. 689.964 Rp. 6.398.486 dan pada skenario 2 dalam rentang Rp. 678.478 Rp. 6.387.000, walaupun tidak signifikan apabila dibandingkan dengan mendaur ulang seluruh material berharga suatu e-waste.

6. Pada daur ulang PCB, kontribusi keuntungan terbesar ada pada kategori small appliances sebesar $70 \%$, disusul kategori medium appliances $(27 \%)$ dan yang terkahir, kategori gadget $(3 \%)$.

7. Komponen biaya terbesar yang harus ditanggung pihak industri pengolah $e$-waste ialah biaya pembelian $e$-waste dengan persentase sebesar $81 \%$.

Adapun saran yang dapat diberikan untuk penelitian selanjutnya ialah:

1. Proyek percontohan pengumpulan sampah elektronik dijalankan berdasarkan sistem value chain management yang telah dibuat dengan sebaiknya menggunakan motor bak sampah dengan kapasitas $200 \mathrm{~kg}$ untuk periode-periode awal proyek agar meminimalisir resiko yang ada apabila sampah elektronik yang dikumpulkan tidak terlalu banyak.
2. Jika hasil pengumpulan sampah elektronik menunjukan hasil pada kondisi muatan yang optimis (90\% full) maka pada proyek selanjutnya, kapasitas motor bak sampah dapat di-upgrade menuju tingkat berikutnya.

3. Proyek percontohan pengumpulan e-waste dapat dilakukan melalui diadakannya suatu event seperti lomba berhadiah ataupun door prize yang diadakan setiap 2 bulan sekali sehingga memunculkan motivasi dari masyarakat untuk mengumpulkan $e$ waste karena adanya insentif langsung yang diberikan.

4. Untuk penelitian selanjutnya, dapat ditambahkan gaji pekerja ataupun komponen biaya lainnya pada simulasi agar hasil yang didapat lebih sesuai dengan kondisi yang ada

\section{Daftar Pustaka}

Agustina, H. (2011). "The Challenge of E-Waste Management (Indonesian Experience)." The WEEE/E-Waste Management Workshop on TakeBack System. Osaka: UNEP..

Antara, (2015, 3 Maret). Indonesia Perlu Kerja Keras Tangani Sampah. http:/ / www.antara.net.id/index.php/2015/ 03/03/indonesia-perlu-kerja-keras-tanganisampah/id/ (diakses pada 15 September 2015).

CalRecycle, (2015, 9 April). Retailer Information \& Electronic Waste Recycling Fee. http:/ / www.calrecycle.ca.gov/Electronics / Retailer/ (diakses pada 15 September 2015).

Chatterjee, S., (2012). "Sustainable Electronic Waste Management and Recycling Process ." American Journal of Environmental Engineering, p.23-33.

Cucchiella, Federica, Idiano D'Adamo, Lenny Koh, dan Paolo Rosa., (2015). "Recycling of WEEEs: An economic assessment of present and future e-waste streams." Renewable and Sustainable Energy Reviews 51 ,p.263-272.

Dalrymple, I., N. Wright, R. Kellner, N. Bains, K. Geraghty, and M. \& Lightfoot L. Goosey., (2007). "An integrated approach to electronic waste (WEEE) recycling." Circuit World, p.5258 . 
Geyer, Roland, dan Vered Doctori Blass., (2010). "The economics of cell phone reuse and recycling." The International Journal of Advanced Manufacturing Technology, p.515-525.

Halim, Audry V., (2011). Perilaku Konsumen Dan Analisis Faktor Kesediaan Penduduk DKI Jakarta Dalam Mendaur Ulang Limbah Elektronik rumah Tangga. Tugas Akhir Strata Satu Jurusan Teknik Industri , Tangerang: Universitas Pelita Harapan.

Hendrawan, Parliza., (2012, 15 April). Indonesia Hasilkan 625 Juta Liter Sampah Sehari. http://nasional.tempo.co/read/news/2012/ 04/15/063397147/indonesia-hasilkan-625juta-liter-sampah-sehari (diakses pada September 12, 2015).

Porter, Michael E., (1998). The Competitive Advantage: Creating and Sustaining Superior Performance. New York: Free Press.

Printed Circuit Industry Federation., (2002). A Scoping Study End-of-Life Printed Circuit Boards. Scoping Study, London: Shipley Europe Limited.

Sterman, John D., (2002). Business Dynamics. Boston: McGraw-Hill.

Waste \& Resources Action Programme., (2009). Compositional Analysis of Kerbside Collected Small WEEE. Reasearch, Suffolk: WRAP MDD009.

Womack, James P., and Daniel T. Jones., (1996). Lean thinking: Banish waste and create wealth in your corporation. New York: Free Press.

$\mathrm{Wu}$, Luo XJ, Zhang Y, Luo Y, Chen SJ, and et al Mai BX., (2008). "Bioaccumulation of polybrominated diphenyl ethers (PBDEs) and polychlorinated biphenyls (PCBs) in wild aquatic species from an electronic waste (ewaste) recycling site in South China." Environ Int. 